\title{
APPLICATION OF SOME STRAINS OF FLUORESCENT PSEUDOMONADS IN MANAGING ROOT-INFECTING PATHOGENS OF MAIZE
}

\author{
Abdel Azeez ${ }^{1}$, O.E.; Enas, A.Hassan ${ }^{2}$; E.M. El-Assiuty ${ }^{1}$ and E.M. Ramadan ${ }^{2}$ \\ 1- Plant Pathology Res. Inst., Agric. Research Center, Giza, Egypt \\ 2- Agric. Microbiology Dept., Fac. of Agric., Ain Shams Univ., Cairo, Egypt
}

Keywords: Maize; Fluorescent pseudomonads; Cephalosporium maydis; Fusarium verticillioides; Biological control

\section{ABSTRACT}

Possibility of manipulating some of the efficient strains of fluorescent pseudomonads to manage the root-infecting pathogens of maize was studied throughout this study. Out of 110 isolates 24 of Pseudomonas species, recovered from the plant rhizosphere showed to have inhibitory effect against two major root-infecting pathogens of maize, namely Cephalosporium maydis and Fusarium verticillioides in vitro. Pot experiment revealed that just 4 isolates could reduce infection with both pathogens and enhance the plant growth as well. Based on the genotypic identifications of these four isolates showed that they were: Pseudomonas putida strain Pau9, $P$. putida strain Pau11, $P$. putida strain Psf3 and $P$. aeruginosa strain Psf9.

\section{INTRODUCTION}

Root-infecting pathogens can cause serious diseases to field crops under unfavorable conditions. Maize plants are subjected to several soil borne pathogens. In Egypt, late-wilt caused by Cephalosporium maydis is the most serious and wide spread fungal pathogen that can infect plants through roots of susceptible varieties and hybrids causing 30-40\% grain losses in infected plants (Abdel-Rahim, 1971). The second serious fungal pathogen is Fusarium verticillioides, which infects maize plants at seedling stage, causing wilting and death (Rheeder et al 2002; Duncan and Howard, 2010). These two root-infecting pathogens are of concern in the time being (El-Assiuty et al 1998; Alakonya et al 2008). It is extremely difficult to control soil-borne pathogens by fungicides. Thus, biological control is being considered a supplemental method of reducing the use of chemicals in agriculture to the benefit of manhood (Kloepper et al 1999 and Widmer et al 1998). Plant growth promoting rhizobacteria (PGPR) have been applied to seed and soil successfully for years (Kloepper et al 1999). Fluorescent pseudomonads, an important component of PGPR have been reported by several investigators as efficient bioagents in controlling major diseases of different diseases plants (Sharma et al 2014 and Minaxi \& Saxena, 2010).

Therefore study aimed to apply some efficient isolates of fluorescent pseudomonads recovered from plant rhizosphere to decrease infection with major root pathogens of maize.

\section{MATERIALS AND METHODS}

\section{Fungal pathogens}

Cephalosporium maydis (=Harpophora maydis), and Fusarium verticillioides (=F.moniliforme) were recovered from maize plants showing signs of infection, collected from Etsa, Fayoum governorate. Kokh's postulates were followed and the most efficient pathogenic isolate from each of the target pathogens was chosen in present study. They were compared with the culture collection of Plant Pathology Research Institute, ARC and kept in $15 \%$ glycerol under $-80^{\circ} \mathrm{C}$ for prolonged period.

\section{Isolation of fluorescent pseudomonads}

Isolates of fluorescent pseudomonads were recovered from the rhizosphere of maize and sugar beet grown in different geographical locations (governorates) during 2014. Root samples were 
washed vigorously with tap water, shaken to remove excess soil and left to dry. Rhizosphere $(0.5 \mathrm{~g})$ along with $4.5 \mathrm{ml}$ phosphate buffer were shaken at $120 \mathrm{rpm}$ for $10 \mathrm{~min}$. Serial ten-fold dilutions were prepared, $0.5 \mathrm{ml}$ of suitable diluents were spread onto King's medium (King et al 1954 and Amkraz et al 2010) and incubated at $28^{\circ} \mathrm{C}$ for 1-2 days. Thereafter, isolated single colonies were picked up and restreaked on fresh King's agar plates and incubated similarly. Purified bacterial colonies were examined for fluorescence under UV at 265and $356 \mathrm{~nm}$ and Gram staining. Pure isolates were preserved into slants on King's medium at $5^{\circ} \mathrm{C}$. The pure cultures were preserved in $15 \%$ glycerol under $-80^{\circ} \mathrm{C}$ until use.

\section{In vitro antagonistic activity}

The obtained isolates of Pseudomonas spp. were tested for their efficiency for inhibiting the linear growth of both target pathogens by inoculating a $(0.5 \mathrm{~cm}$ diam.) disc from each of the fungal pathogens at the center of Waksman's plate (Berg et al 2002) at $28^{\circ} \mathrm{C}$. After 24 h., 4 different bacterial isolates were streaked at the same distance from the fungal disc. Plates were incubated at the same degree of temperature for three days. Three replicate plates were used. Results were recorded as positive or negative effect of the bacterial isolate for antagonizing the target pathogens.

\section{In vivo evaluation of antagonisting bacterial isolates}

Fungal inoculants were prepared by inoculating the pathogens individually into autoclaved sorghum grains and incubated at room temperature for a sufficient period (about 2 weeks). Thereafter; potted-soil silt clay soil was infested singly with each of the fungal inoculum at the rate of $2.5 \%$ $(w / w)$. Pots were moistened to permit the pathogens to establish growth for one week before planting. Seed of a sensitive local Zea mays variety were coated with each of the bacterial isolate following the method described by Bardin et al. (2004). Each set of the bacterial treated seed were planted in the prepared potted soil (no.25) and the experiment was quadruplets. Cultural practices (irrigation fertilization,...etc.) were made as usual. Percentage of seedling emergence and plant stand (survival plants) were recorded after 15 and 45 days of planting, respectively.

\author{
Biochemical characterization of Pseudomonas \\ spp.
}

The bacterial isolates were characterized biochemically as described by Buchanan and Gibbson (1974).

\section{Molecular identification of Pseudomonas spp.}

\section{Sequence analysis of 16S rRAN gene}

Isolation of cellular DNA was performed as described by Ausubell et al (1987). DNA was extracted by thermo scientific genejet gel extraction kit. Relevant16S rDNA sequences are available in Gene Bank and done by Bio Basic, Canada Inc. Sequence of the used primer described by Spilker et al (2004) is shown in Table (1). PCR amplification of targeted DNA was carried out in $50 \mu \mathrm{l}$ reaction volume (Master mix Bioline, 25 $\mu$; ; primer F2 $\mu$; primer R, $2 \mu \mathrm{l}$; DNA $5 \mu \mathrm{l} ; 16 \mu \mathrm{l})$. DNA was amplified over 25 cycles of denaturation for $2 \mathrm{~min}$ at $95^{\circ} \mathrm{C}$, each consisting of $20 \mathrm{~s}$ at $94^{\circ} \mathrm{C}, 20 \mathrm{~s}$ at the annealing temperature of $54^{\circ} \mathrm{C}$ and extension for $40 \mathrm{~s}$ at $72^{\circ} \mathrm{C}$. Thereafter, a final extension was applied for $1 \mathrm{~min}$ at $72^{\circ} \mathrm{C}$ (Spilker et al 2004). Amplification of DNA product was run on $1 \%$ agarose gel (ROKO Poligono De Silvota, Spain) and separated by electrophoresis in 1x TBE buffer. DNA gel was photographed with ethidium bromide under UV by transilluminator. PCR product was purified and sequenced by Sigma Company.

\section{Phylogenetic analysis}

Sequences were compared with sequences of Pseudomonas spp. available in the Gene Bank NCBI database (National Center for Biotechnology Information) using BLAST search network services for similarities present in Gene Bank database. Multiple sequence alignments from all sequences of each gene were performed using Clustal W version 2.0 (Larkin et al 2007). Phylogenetic analyses were constructed by the maximum likelihood (ML) method with maximum parsimony (MP) using MEGA version 7 (Kumar et al 2016). The bootstrap values illustrated on the phylogenetic trees were generated with 1000 replicate heuristic searches. 
Table 1. Sequence of specific primer used in identifying Pseudomonas spp.

\begin{tabular}{|c|c|c|c|c|c|}
\hline \multicolumn{1}{|c|}{ Primer } & Sequence $\left(5^{\backslash}-3^{\prime}\right)$ & Target & $\begin{array}{c}\text { Annealing } \\
\text { temp. }\left({ }^{\circ} \mathrm{C}\right)\end{array}$ & Location $^{a}$ & $\begin{array}{c}\text { Product } \\
\text { size (bp) }\end{array}$ \\
\hline PA-GS-F & GACGGGTGAGTAATGCCTA & Pseudomonas sp. & 54 & $95-113$ & 618 \\
PA-GS-R & CACTGGTGTTCCTTCCTATA & & $693-712$ & \\
\hline
\end{tabular}

\section{Statistical analysis}

Data were subjected to analysis of variance using SAS-9.1 software (SAS Institute, 2003). Mean values among treatments were compared by L.S.D $\mathrm{P}<0.05$.

\section{RESULTS}

\section{Isolation of the fluorescent pseudomonads}

Fluorescent pseudomonads were isolated from rhizosphere of maize and sugar beet plants grown in different governorates and its numbers were presented in Table (2).

Table 2. Number of fluorescent pseudomonad isolates recovered from maize and sugar beet rhizosphere grown at different governorates

\begin{tabular}{|l|c|c|c|}
\hline \multirow{2}{*}{ Governorate } & \multirow{2}{*}{$\begin{array}{c}\text { No. } \\
\text { isolates }\end{array}$} & \multicolumn{2}{|c|}{ Source } \\
\cline { 3 - 4 } & & Maize & $\begin{array}{c}\text { Sugar } \\
\text { beet }\end{array}$ \\
\hline Fayioum & 33 & 9 & 24 \\
Sharqiya & 32 & 10 & 22 \\
Beheira & 15 & 5 & 10 \\
Gharbiya & 15 & - & 15 \\
Giza & 15 & 10 & 5 \\
\hline Total isolates & $\mathbf{1 1 0}$ & $\mathbf{3 4}$ & $\mathbf{7 6}$ \\
\hline
\end{tabular}

Data in Table (2) show that 110 isolates of fluorescent pseudomonads were recovered from different governorates and the most isolates were collected from maize and sugar beet plants grown in Fayoum and Sharqiya governorates being 33 and 32 isolates, respectively.

\section{Antifungal activity}

All of the recovered isolates of fluorescent pseudomonads were assayed in vitro for antagonism against both of the target pathogens. Each pathogen showed different levels of sensitivity toward the bacterial isolates. Positive effect was clearly recognized by limiting the fungal growth or by complete inhibition of fungal mycelia. Results showed that 30 bacterial isolates having the potential effect against C. maydis, while, 27 isolates affected the linear growth of F.verticillioides. About $50 \%$ of bacterial isolates under study were unable to inhibit the growth of any of the target pathogens. Out of these, 24 isolates were showed to have high antagonistic effect against both pathogens. Accordingly, they were selected for further study.

\section{In vivo evaluation}

Data presented in Table (3) explain the effect of coating maize seeds with each of the 24 bacterial isolates on seedling emergence (after 15 days of planting) and plant stand (after 45 days of planting) along with infection percentage at each of the plant growth in soil infested, separately with each of $C$. maydis and $F$. verticillioides. As regards to potted-soil infested with $C$. maydis, significant differences were found between percentage of seedlings emerged from seeds treated with any of the bacterial isolates comparable to the infested control, except four isolates no. Psf 2, Pmf 17, Psf 30 and Psf 31, where no increase in the emergence was found. In contrast, in potted-soil infested with F. verticillioides, seedling emergence was nonsignificant differences by treating with the majority of bacterial isolates, while isolates no. Psf 33, Pssh 39, Pssh 50, Pau9, Pau10, Pau11 and Pau12 were the most effective in increasing seedling emergence comparable to the infested control.

After 45 days of planting, however, data of plant stand were taken and recorded as percentage of the survived plants from emerged seedling. Infection was calculated as the percentage of the diseased plants at this stage of plant growth. Data presented in Table (3) show that most of isolates significantly reduced infection in soil infested with any of the target pathogens comparable with the non-treated-infested control, generally. But, isolate no. Pssh 48 failed in decreasing infection in C. maydis-infested soil. Also, isolates no. Pssh 48 and Psf11could not significantly affect the plant stand or infection percent with $F$. verticillioides. 
Table 3. Efficiency of coating maize seed with fluorescent pseudomonad isolates in managing rootinfecting pathogens of maize under greenhouse conditions, 2015

\begin{tabular}{|c|c|c|c|c|c|c|c|c|}
\hline \multirow[b]{2}{*}{ Isolate No. } & \multicolumn{4}{|c|}{ C.maydis-infested-soil } & \multicolumn{4}{|c|}{ F.verticillioides-infested-soil } \\
\hline & $\begin{array}{l}\% \text { Seedling } \\
\text { emergence }\end{array}$ & $\begin{array}{l}\text { \%Seedling } \\
\text { infection }\end{array}$ & $\begin{array}{c}\% \text { Plant } \\
\text { stand }\end{array}$ & $\begin{array}{c}\text { \%Plant } \\
\text { infection }\end{array}$ & $\begin{array}{l}\text { \%Seedling } \\
\text { emergence }\end{array}$ & $\begin{array}{c}\% \text { Seedling } \\
\text { infection }\end{array}$ & $\begin{array}{c}\% \text { Plant } \\
\text { stand }\end{array}$ & $\begin{array}{c}\text { \%Plant } \\
\text { infection }\end{array}$ \\
\hline Psf 1 & 72.50 & 27.50 & 48.27 & 51.73 & 60.00 & 40.00 & 79.16 & 20.84 \\
\hline Psf 2 & 57.50 & 42.50 & 47.82 & 52.18 & 72.50 & 27.50 & 75.86 & 24.14 \\
\hline Psf3 & 65.00 & 35.00 & 61.53 & 38.47 & 55.00 & 45.00 & 90.90 & 9.10 \\
\hline Psf 4 & 67.50 & 32.50 & 59.25 & 40.75 & 65.00 & 35.00 & 65.38 & 34.62 \\
\hline Psf9 & 62.50 & 37.50 & 84.00 & 16.00 & 57.50 & 42.50 & 91.30 & 8.70 \\
\hline Psf 10 & 62.50 & 37.50 & 60.00 & 40.00 & 57.50 & 42.50 & 78.26 & 21.58 \\
\hline Psf 11 & 77.50 & 22.50 & 64.51 & 35.49 & 67.50 & 32.50 & 37.04 & 62.96 \\
\hline Pmf 17 & 52.50 & 47.50 & 66.66 & 33.34 & 70.00 & 30.00 & 46.42 & 53.58 \\
\hline Psf 27 & 70.00 & 30.00 & 75.00 & 25.00 & 75.00 & 25.00 & 46.66 & 53.34 \\
\hline Psf 30 & 55.00 & 45.00 & 68.18 & 31.82 & 75.00 & 25.00 & 60.00 & 40.00 \\
\hline Psf 31 & 55.00 & 45.00 & 54.54 & 45.46 & 62.50 & 37.50 & 40.00 & 60.00 \\
\hline Psf 32 & 72.50 & 27.50 & 62.06 & 37.94 & 65.00 & 35.00 & 50.00 & 50.00 \\
\hline Psf 33 & 67.50 & 32.50 & 70.37 & 29.63 & 80.00 & 20.00 & 56.25 & 43.75 \\
\hline Pssh34 & 70.00 & 30.00 & 75.00 & 25.00 & 72.50 & 27.50 & 41.37 & 58.63 \\
\hline Pssh 38 & 75.00 & 25.00 & 62.06 & 37.94 & 72.50 & 27.50 & 41.37 & 58.63 \\
\hline Pssh 39 & 75.00 & 25.00 & 73.33 & 26.67 & 77.50 & 22.50 & 61.29 & 38.71 \\
\hline Pssh 48 & 67.50 & 32.5 & 33.33 & 66.67 & 65 & 35 & 30.76 & 69.24 \\
\hline Pssh 50 & 72.50 & 27.50 & 55.17 & 44.83 & 82.50 & 17.50 & 54.54 & 45.46 \\
\hline Pah3 & 80.00 & 20.00 & 62.06 & 37.94 & 62.50 & 37.50 & 75.67 & 24.33 \\
\hline Pah5 & 75.00 & 25.00 & 70.00 & 30.00 & 90.00 & 10.00 & 72.22 & 27.78 \\
\hline Pau9 & 80.00 & 20.00 & 84.37 & 15.63 & 95.00 & 5.00 & 84.21 & 15.79 \\
\hline Pau 10 & 75.00 & 25.00 & 66.66 & 33.34 & 87.50 & 12.50 & 65.71 & 34.29 \\
\hline Pau 11 & 77.50 & 22.50 & 87.09 & 12.91 & 97.50 & 2.50 & 76.92 & 23.08 \\
\hline Pau 12 & 92.50 & 7.50 & 64.86 & 35.14 & 85.00 & 15.00 & 61.76 & 38.24 \\
\hline $\begin{array}{l}\begin{array}{l}\text { Cont. } \\
\text { (infected) }\end{array} \\
\end{array}$ & 37.50 & 62.50 & 33.33 & 66.67 & 57.50 & 42.50 & 38.38 & 61.62 \\
\hline $\begin{array}{l}\text { Cont. } \\
\text { (non- infected) }\end{array}$ & 98.50 & 1.50 & 98.00 & 2.00 & 99.00 & 1.00 & 97.50 & 2.50 \\
\hline LSD & 23.84 & -- & 24.54 & -- & 19.45 & -- & 25.89 & -- \\
\hline
\end{tabular}

Data in Table (3) also indicat that Psf9, Pau9 and Pau11 showed to be highly effective in reducing infection with C. maydis and Psf3, Psf9 and Pau9 where they were high efficient in controlling infection with $F$. verticillioides. Therefore, isolates no. Psf9, Pau9, Pau11and psf3 were selected for further study in the present work.

\section{Biochemical characterization of fluorescent pseudomonads}

The most potent isolates of fluorescent pseudomonads under study were tentatively characterized following Bergy's manual (Buchanan and Gibbson 1974). Results of characterization are presented in Table (4). 
Table 4. Biochemical characterization for tentative identification of isolated Pseudomonas spp.

\begin{tabular}{|c|c|c|c|c|c|c|c|c|c|c|c|c|c|c|}
\hline $\begin{array}{l}\bar{\Phi} \\
\frac{0}{\tilde{N}} \\
\frac{\vec{D}}{D}\end{array}$ & $\begin{array}{l}\frac{\Omega}{0} \\
\frac{0}{3} \\
0 \\
\frac{0}{3} \\
\frac{0}{3}\end{array}$ & 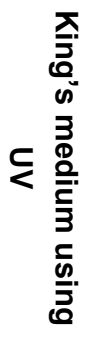 & 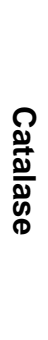 & $\begin{array}{l}\text { 즈 } \\
\text { 무 } \\
\text { மo }\end{array}$ & 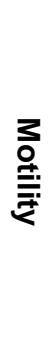 & 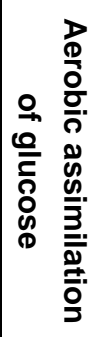 & 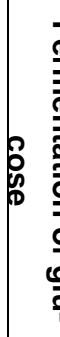 & $\begin{array}{l}\frac{0}{0} \\
\frac{0}{3} \\
\frac{0}{2} \\
\frac{0}{0} \\
\frac{0}{0} \\
\frac{2}{2} \\
\frac{0}{7} \\
\frac{0}{3}\end{array}$ & 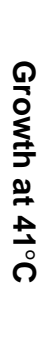 & 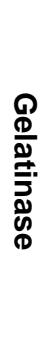 & 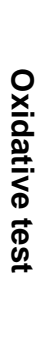 & 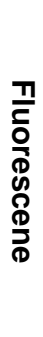 & $\begin{array}{l}\text { 무 } \\
\text { ○) } \\
\text { \. }\end{array}$ & 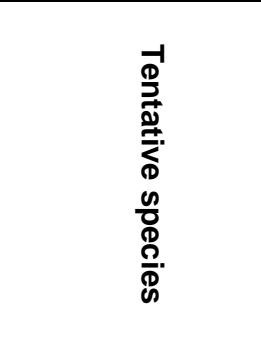 \\
\hline Psf3 & - & $+b$ & + & + & + & + & - & + & - & - & + & + & - & Pseudomonas sp. \\
\hline Psf9 & - & $+b$ & + & + & + & + & - & + & + & - & + & - & + & Pseudomonas sp. \\
\hline Pau9 & - & $+b$ & + & + & + & + & - & + & - & - & + & + & - & Pseudomonas sp. \\
\hline Pau 11 & - & $+b$ & + & + & + & + & - & - & - & - & + & + & - & Pseudomonas sp. \\
\hline
\end{tabular}

b: blue color

Biochemical analysis of the four isolates under study shown in Table (4) confirmed that they are related to Pseudomonas spp.

Results of classical identification for isolates of fluorescent pseudomonads under study needed to be identified up to species following genetic identification. 16S rDNA- based primer sets were used for sequencing the Pseudomonas spp. (Spilker et al 2004).

\section{Genotypic identification for the most potent antagonistic bacterial isolates}

Four rhizobacterial isolates which gave the best results in pot experiment against the target pathogens ( $C$. maydis and $F$. verticillioides) were molecular identified. The phylogenetic analyses according to the BLAST search are shown in Fig. (2). The four isolates were subjected to molecular characterization using the pseudomonas specific primer. A single distinct fragment of approximately $618 \mathrm{bp}$ was observed with the four strains as shown in Fig. (1). Sequencing of $16 \mathrm{~S}$ rDNA from strains, namely Psf 9, Psf3, Pau 9\& Pau11was performed .In order to find out the most similar available sequences, a BIAST search of $16 \mathrm{~S}$ rDNA was done at the NCBI database. Accordingly, the phylogenetic analyses of these pseudomonads based on the maximum likelihood method were identified as follows: Psf3= Pseudomonas putida $K X 786158$ Psf 9= Pseudomonas aeruginosa ss12 GU451299
Pau9=Pseudomonas putida KX786158 Pau11= Pseudomonas putida HF3-27FJ405891 (Fig. 2).

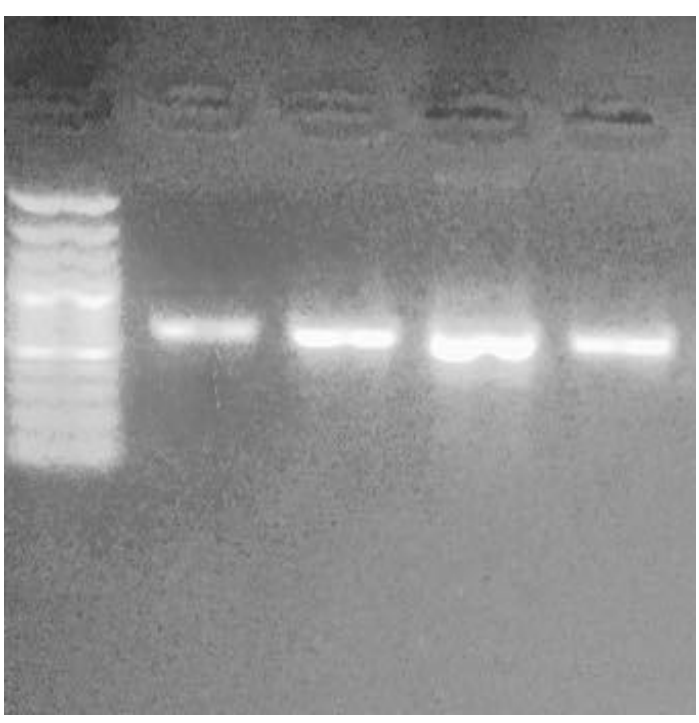

Fig. 1. Agarose gel electrophoresis of the PCRproduct of 16S rDNA sequences from the most potent Pseudomonas strains along with the target primer. Lane1: M1500bp DNA ladder, Lane2:Psf3, Lane3: Psf9, Lane4: Pau9, Lane5: Pau11. 


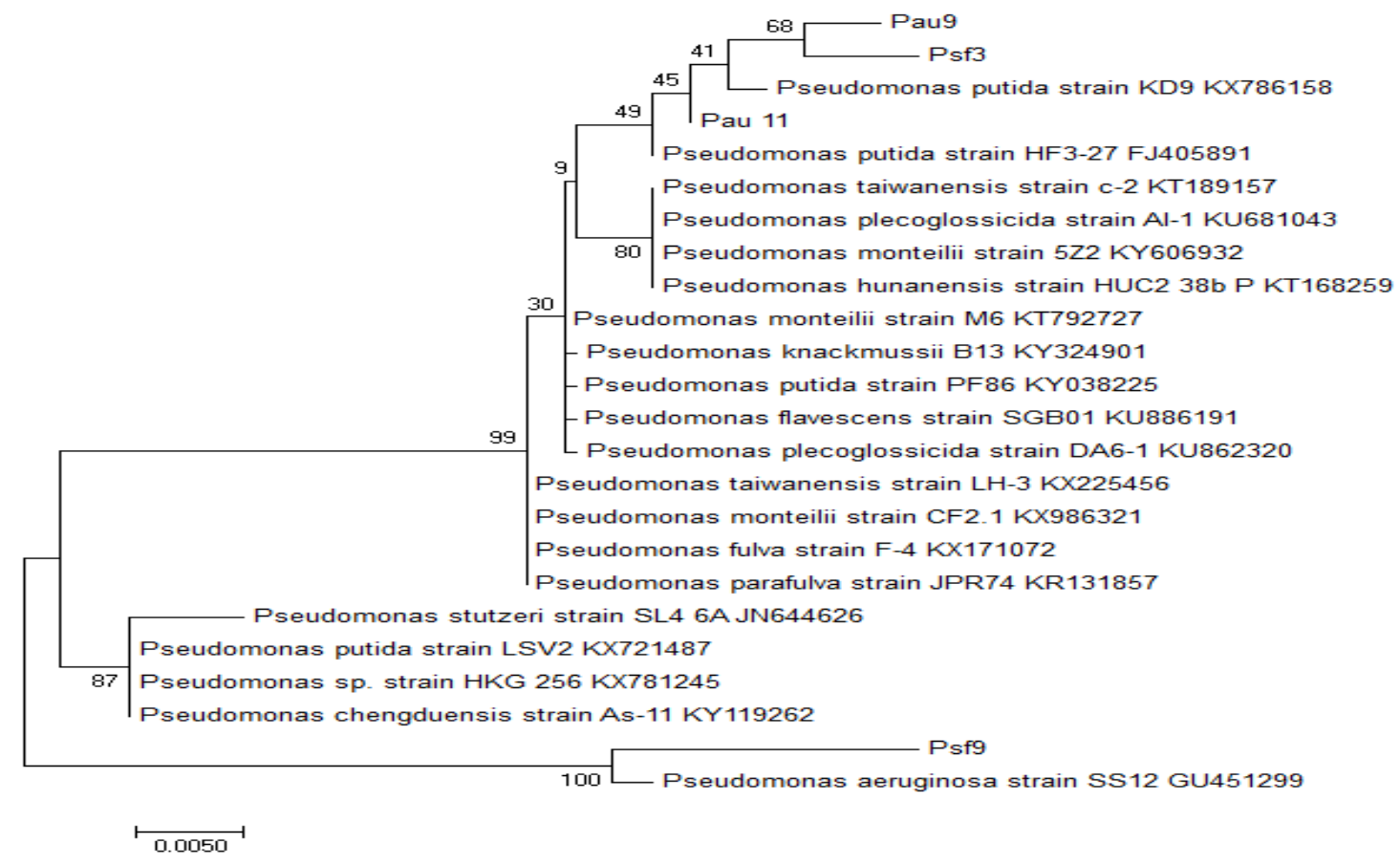

Fig. 2. Phylogenetic tree of tested bacterial strains

\section{DISCUSSION}

Increasing use of chemical inputs causes several negative effects, such as evolving of pathogen resistance to the applied pesticides and their serious environmental impacts. Thus, biological control is being considered a supplemental method for reducing the use of the hazardous chemicals in agriculture. Therefore, current study dealt with managing or decreasing major pathogens of maize plant roots by some efficient fluorescent pseudomonad isolates.

Several isolates of these bacterial group recovered from maize and sugar beet rhizosphere were screened for their efficiency towards the target pathogens, namely Cephalosporium maydis and Fusarium verticillioides. Twenty four isolates were shown to have the potency to antagonize both of the target pathogens in the laboratory. and reduce root infection in pot experiment. Obtained results showed that enhancing plant stands was obviously coincided with the effectiveness in reducing infection with the target pathogens. Inhibitory effect of several strains of this bacterial group were recorded by previous investigators (Minaxi and Saxena, 2010; Noori and Saud, 2012). Altinok et al
(2013), reported that Fusarium wilt of eggplant could be reduced up to $85 \%$. by drenching the seedlings in pot experiment with suspensions from one strain of $P$. putida and two strains of $P$. aerugina. El-Assiuty et al (2010) reported that infection of sugar beet with root-rot could be reduced by coating seed with some strains of fluorescent pseudomonads. This application caused an increase in shoot and root biomass and no signs of abnormalities were observed on applied plants. The antagonistic effect and controlling of rootinfecting diseases could be attributed to the potential of the applied organisms to produce some metabolites such as antibiotics, siderophores, hydrogen cyanide (HCN), ...etc. (Minaxi, and Saxena, 2010; Noori \& Saud, 2012 and Sharma et al 2014). The production of enzymes related to pathogenesis is also, considered the largest property of the antagonistic strains (Saikia et al 2004). Moreover, novel proteins that exhibit antimicrobial activity were stimulated in leaves after foliar application with some fluorescent psudomonads as, recently reported by El-Assiuty et al (2010). Chitinase glucanase were also, found to be substantially increased in leaves of treated plants. Other investigators (Meena et al 2000) who emphasized that 
activities of chitinase and phenylamonia lyase were increased after foliar application of rice with $P$. fluorescens. These hypothesized practical considerations involved in the mode of action of the Pseudomonas strains used in this study support the recommendation of using them to control such diseases biologically.

Biochemical and genotypic identifications were done to the four most potent isolates. According to the phylogenetic analyses based on the maximum likelihood method, they were identified as follows: Psf3= P. putida strain Psf3, Psf9=P.aeruginosa strain Psf9, Pau9=P.putida strain Pau9 and Pau11= P.putida strain Pau11.

Among these identified strains, P.putida and $P$.aeruginosa were reported by several investigators as biocontrol agents (Minaxi \&Saxena, 2010 and Sharma et al., 2014). Furthermore, some strains of these two species were abundantly reported to have the potential to produce some antagonistic metabolites that inhibit the pathogens, in addition to their ability to release of plant growth factors as reported by Altinok et al (2013). The Pseudomonas strains in the current study were found to have the potency to produce some metabolic products such as 4-hydroxybenzoic acid, 2,6di-hydroxyl benzoic acid and hydroquinone (unpublished data). Alleviating infection with plant diseases is hypothesized to be accomplished by these products and others (Smith-Becker et al 1998 and De Werra et al 2011).

Also, Harwood et al (1984) reported that the plant derived aromatic metabolites as Benzoxazinoids (BXs) can act as chemo-attractants for $P$. putida. It was hypothesized by Neal et al (2012) that these compounds are exudated from roots of maize and they may be attractive and supportive to $P$. putida cells. These metabolites were concluded by the same authors to be responsible for mechanism of tolerance provides $P$. putida with a competitive advantage over other microorganisms in maize rhizosphere.

In addition to the efficacy of these strains in managing the root-infecting pathogens, many of these strains having the potency to secrete plant hormones that accelerate and enhance plant growth as stated by Noori and Saud (2012).

In conclusion, present investigation threw the light on the possibility of applying such of these strains to control root-infecting pathogens of maize.

\section{REFFERENCES}

Abdel-Rahim, M.F. 1971. Further Studies on the Effect of Field Conditions and Cultural Practices on Infection with Stalk-Rot Complex of Maize. Ph.D., Fac. of Agric. Univ., of AlAzhar, 235 p.

Alakonya, A.E., Moda, E.O. and Ajan, S. 2008. Management of Fusarium verticillioides root infection control in maize using organic soil amendments. World Appl. Sci. J. 5(2), 161170.

Altinok, H.H., Dikilitas, M. and Nilufer, H.Y. 2013. Potential of Pseudomonas and Bacillus isolates as biocontrol agents against fusarium Wilt of Eggplant. Biotechnology \& Biotechnological Equipment, 27, 3952-3958.

Amkraz, N., Boudyach, E.H., Boubaker, H., Bouizgarne, B. and Ait Ben Aoumar, A. 2010. Screening for fluorescent pseudomonades, isolated from the rhizosphere of tomato, for antagonistic activity toward Clavibacter michiganensis subsp. michiganensis. World J. Microbiol. Biotechnol. 26, 1059-1065.

Ausubell, F.M., Brent, R., Kingston, R.E., Moore, D.D., Seidman, J.G., Smith, J.A. and Struhl, K. 1987. Current Protocols in Molecular Biology, Greene Publishing Associates/Wiley Interscience, New York, USA.

Bardin, S.D., Huang, H.C. and Moyer, J.R. 2004. Control of Pythium damping-off of sugar beet by seed treatment with crop straw powders and a biocontrol agent. Biological Control, 29, 453 $-460$.

Berg, G., Roskot, N., Steidle, A., Eber, L., Zock, A. and Smalla, K. 2002 . Plant-Dependent Genotypic and Phenotypic Diversity of Antagonistic Rhizobacteria Isolated from Different Verticillium Host Plants. Appl. Environ. Microbiol., 68(7), 3328-3338.

Buchanan, R.E. and Gibbson, N.E. 1974. Bergey's Manual of Determinative Bacteriology. The Williams and Wilkins Co., Baltimore. $8^{\text {th }}$ ed. Williams \& Wilkins Co., Baltimore, Md., 1246 p.

De Werra, P., Huser, A., Tabacchi, R., Keel, C. and Maurhofer, M. 2011. Plant and microbederived compounds affect the expression of antifungal genes in a biocontrol pseudomonad. Appl. Environ. Microbiol., 77(8), 2807-2812.

Duncan, K.E. and Howar, R.J. 2010. Biology of maize kernel infection by Fusarium verticillioides. Molecular Plant-Microbe Interactions 23, 6- 16. 
El-Assiuty, E.M., El-Shafey, H.A., Ismail, A.M., Fahmy, Zeinab M. and Zein El-Abedeen, A. 1998. Pathogenic variation in Cephalosporium maydis. Phytopathology, 88(25), 450-470.

El-Assiuty, E.M., Rizk, M.A. and Ibrahim, A.E. 2010. Changes in nutrient contents and protein induction in Cercospora beticola-infected sugar beet plants in relation to treatments of some bioagents. Egypt. J. Appl. Sci., 25(8), 326-339.

Harwood, C.S; Rivelli, M. and Ornston, L.N. 1984. Aromatic acids are chemoattractants for Pseudomonas putida. J. Bacteriol 160, 622628.

King, E.O., Ward, M.K. and Raney, D.E. 1954. Two simple media for the demonstration of pyocyanin and fluorescin. J. Lab Clin Med 44, 301-307.

Kloepper, J.W., Rodriguez-Ubana, R., Zehnder, G.W., Murphy, J.F., Sikora, E. and Fernandez, C. 1999. Plant root-bacterial interactions in biological control of soil borne diseases and potential extension to systemic and foliar diseases. Austral. Plant Pathol. 28, 21-26.

Kumar, S., Stecher, G. and Tamura, K. 2016. MEGA7: molecular evolutionary genetics analysis version 7.0 for Bigger Datasets. Mol. Biol. Evol., 33(7), 1870-1874.

Larkin, M.A., Blackshields, G., Brown, N.P., Chenna, R.Mc. Gettigan, P.A., McWilliam, H., Valentin, F., Wallace, I.M., Wilm, A., Lopez, R., Thompson, J.D., Gibson, T.J. and Higgins D.G. 2007. Clustal $W$ and Clustal $X$ version 2.0. Bioinformatics 23(21), 2947-2948.

Meena, B., Radhajeyalakshmi, R., Vidhyasekaran, P. and Velazhahan, R. 2000. Effect of foliar application of Pseudomonas fluorescenson activity of phenylalanine and B-1,3-glucanase and accumulation of phenolics in rice. Acta Phytopathologica et Entomologica Hungarica, 34(4), 307-315.

Minaxi, and Saxena, J. 2010. Characterization of Pseudomonas aeruginosa RM-3 as a potential biocontrol agent. Mycopathologia 170, 181-193.

Neal, A.L., Ahmed, S., Gordon-Weeks, R. and Ton, J. 2012. Benzoxazinoids in root exudates of maize attract Pseudomonas putida to the rhizosphere. Plos one 7(4), 1-10.

https://doi.org/10.1371/journal.pone.0035498

Noori, M.S.S. and Saud, H.M. 2012. Potential plant growth-promoting activity of Pseudomonas sp. isolated from paddy soil in malaysia as biocontrol agent. J. Plant Pathol. Microb. 3(12), 2157-2161.

Rheeder, J.P., Marasas, W.F.O. and Vismer, H.F. 2002. Production of fumonisin analogs by Fusarium species. Appl. Environ. Microbiol., 68, 2101-2105.

Saikia, R., Kumar, R., Singh, T., Srivastav, A.K., Arora, D.K. and Lee, M.W. 2004. Induction of defense related enzymes and pathogenesis related proteins in Pseudomonas fluorescens treated chickpea in response to infection by Fusarium oxysporum f. sp. ciceri. Mycobiology. 32, 47-52.

Sharma, P.K., Fu, J., Zhang, X., Fristensky, B., Sparling, R. and Levin, D.B. 2014. Genome features of Pseudomonas putida LS46, a novel polyhydroxyalkanoate producer and its comparison with other $P$. putida strains. AMB Express. $37 \mathrm{p}$.

Smith-Becker, J., Marois, E., Huguet, E.J., Midland, S.L., Sims, J.J. and Keen, N.T. 1998. Accumulation of salicylic acid and 4hydroxybenzoic acid in phloem fluids of cucumber during systemic acquired resistance is preceded by a transient increase in phenylalanine ammonia-lyase activity in petioles and stems. Plant Physiol. 116, 231 - 238.

Spilker, T., Coenye, T., Vandamme, P. and LiPuma, J.J. 2004. PCR-Based assay for differentiation of Pseudomonas aeruginosa from other Pseudomonas species recovered from cystic fibrosis patients. J. Clin. Microbiol., 42(5), 2074-2079.

Widmer, F., Seidler, R.J., Patrick M., Gillevet, Watrud, L.S. and Di Giovanni, G.D. 1998. A Highly Selective PCR Protocol for Detecting 16S rRNA Genes of the Genus Pseudomonas (SensuStricto) in Environmental Samples. Appl. Environ. Microbiol., 64(7), 2545-2553. 